of large-scale construction, yet he found paper, sealing wax, wire and steel knitting needles very adequate materials for making a working model of his air turbine. When the late Lord Rayleigh had occasion to set up a pair of mirrors for Fresnel's interference experiment he mounted them in a few minutes on two lumps of soft wax. The amateur method is not only much cheaper but also often takes little more time than the dispatch of an order to the instrument maker. Progress, too, can be made while the mind is red-hot upon the project, before delay has cooled enthusiasm. Little sympathy is shown for the research worker who puts the responsibility for designing his apparatus upon a firm of instrument makers. Lord Rutherford is quoted as saying that, if necessary, he could carry out research at the North Pole. J. C. McConnel, who was compelled for health reasons to winter in Switzerland out of reach of laboratories or facilities of any kind, still made important observations on the crystallization of ice, noting in particular how large were the individual crystals and how they behaved under bending forces when single crystal rods were cut in various directions. Lord Rayleigh paid a tribute to the instrument making industry and its part in practical life and non-pioneering research.

\section{The New Carnegie Cyclotron}

A NEW giant cyclotron has recently been put into operition at the Department of Terrestrial Magnetism of the Carnegie Institution of Washington. The new cyclotron, one of the two largest in operation in the world (the other being at Berkeley, California), generates particles of $15,000,000$ electron volts energy, permitting the most precise measurements ever made of the forces released by atomic disintegration. The cyclotron itself weighs more than 225 tons, has an overall height of $12 \mathrm{ft}$.; it is $30 \mathrm{ft}$. long and $20 \mathrm{ft}$. wide. It took four years to build, at a total cost of 500,000 dollars for the cyclotron, its appurtenances, and the special three-story building housing the equipment and instrument shop. The magnet is made up of four iron castings, the largest weighing more than fifty tons. Surrounded by this heavy magnet is the accelerating chamber, about sixty inches in diameter, in which atomic particles are produced. The cyclotron is housed ten feet below ground.

\section{A New Type of Still}

THE Bulletin and Laboratory Notes of September 1943, issued by Messrs. Baird and Tatlock, Ltd., Esher, Surrey, contains a description of an interesting copper and glass still for the preparation of distilled water in the laboratory. The water is boiled by an electric immersion heater in a tinned copper boiler, with a water-sealed lid of the same material. The lid carries a central metal tube over which is a glass hood communicating by a backward-sloping glass tube to the special water-cooled spiral glass condenser. A horizontal baffle inside the lid under the central steam outlet minimizes the passage of spray into the hood, which also servies as a trap. More than 90 per cent heating efficiency is claimed. The standard model has a $1.8 \mathrm{~kW}$. motor and produces $2 \cdot 7$ lit. of distilled water per hour, with a total water consumption of 36 lit. The water, in a particular experiment, had a $p \mathbf{H}$ of $6 \cdot 0-6 \cdot 2$, and conductivity $1 \cdot 5-2 \cdot 0$ gemmohs, although these figures will vary with the quality of the tap water. Oil or gas heating may be used in emergency. The whole apparatus is conveniently mounted in one piece by suitable clamps and appears to be very robust, and an additional feature is that a supply of hot cooling water can be diverted to a tank near a sink and used for washing. Other interesting types of stills are also described in the Bulletin.

\section{Institute of Industrial Administration: Awards}

THE Institute of Industrial Administration has awarded the Institute travelling scholarship to Mr. A. G. Irvine for his thesis on "The Purposes and Techniques of Market Research". This scholarship, of the value of $£ 250$, enables the holder to spend three months in the United States studying American practice in his particular field of management, assisted by the New York office of the donors of the scholarship, Messrs. Stevenson, Jordan and Harrison, Ltd. The Wilson Medal of the Institute has been awarded to Mr. A. W. Goldstaub, for his paper on "Internal Audit in Industry". The Junior Executive Prize of books to the value of $£ 5$ has been won by Dr. W. L. Kent, for his paper on "The Application of Science to Industry", and Mr. G. Kinnaird Evens, for his paper on "The Future of Psychology in Industry".

\section{"Books: The Warehouse of Knowledge"}

WIтH reference to the leading article "Books: the Warehouse of Knowledge", published in Nature of September 9, p. 319, Mr. Stanley Unwin writes : "If the established book publishers had as much as 5 per cent of 'the paper in the country available for printing' they would be in clover. The total of 420,000 which you give merely includes four categories of paper consumers and omits all others such as the printers. At the beginning of the War it was estimated that books called for about $1 \frac{1}{4}$ per cent of the total. It is unlikely even to-day that the figure exceeds 2 per cent." We regret our error in stated percentage of paper available, and since it was a considerable over-estimate, Mr. Unwin's correction adds still further point to our argument. It may be possible, however, that even Mr. Unwin's figures need correction, so far as books are concerned, for, as The Bookseller of September 14 points out: "These usages, however, do not consume all the paper available for printing. There is, in addition, an unknown but obviously considerable quantity of printing paper employed outside the above categories; for instance, the paper used in company reports, trade catalogues, and for a large variety of other commercial purposes".

\section{Announcements}

The title of reader in timber technology in the University of London has been conferred on Dr. F. Y. Henderson in respect of the post held by him at the Imperial College of Science and Technology.

Mr. F. E. Hughes (assistant conservator of forests, Gold Coast) has been appointed senior assistant conservator of forests, Gold Coast.

According to the August issue of the AngloSwedish Review, the birth-rate figure in Sweden for the first quarter of 1944 of 33,261 was the highest recorded for this period since 1921; the figures for the corresponding period in 1943 and 1942 were 30,079 and 26,240 respectively. More children were born in the towns than in the country, the birth-rate figure for Stockholm being especially high. 